\title{
STUDYING THE BEHAVIOR OF COMPOSITE SLAG BEAM UNDER SHEAR STUD CONNECTOR IN TENSION AND COMPRESSION ZONES
}

\author{
Hamadallah Al-Baijat \\ Associate Professor, Civil Engineering Department, \\ Tafila Technical University, Tafila, Jordan
}

\begin{abstract}
Every year, the quantity of slag produced in Jordan from steel making is approximately 500,000 ton. This huge amount of slag caused environmental and disposal problems. To solve these problems, research has been carried out to use part of the slag as base course in road making and as aggregate in concrete mixes.

The present work used composite beam with shear stud connector and replaced the conventional aggregate by slag at 100\%, 75\%, 50\%, 25\%, and $0 \%$ (limestone) proportions. The experimental results show increase in stress of about $36.7 \%$ when replacing all limestone aggregate with slag. This indicates that the slag aggregates enhanced the strength of the structural element in building and reduced the deflection. Similarly, the strain is reduced in the slag composite beam (as compared with that in limestone beams with zero slag). Consequently, improvement in the modulus of elasticity and stiffness of structural elements occurred. It can be concluded that including slag in beams improves their mechanical properties and may at least partly alleviate the environmental problems arising from production of steel. The presence of shear stud welded on the web prevent the slipping between concrete and steel as seen in the testing of specimens.
\end{abstract}

Keywords: shear stud; steel slag; durability; replacement, Jordan

Cite this Article: Hamadallah Al-Baijat, Studying the Behavior of Composite Slag Beam under Shear Stud Connector in Tension and Compression Zones. International Journal of Advanced Research in Engineering and Technology, 10(4), 2019, pp. 94101.

http://iaeme.com/Home/issue/IJARET?Volume=10\&Issue $=4$

\section{INTRODUCTION}

Shear studs are usually connected to the top flange steel girder of bridges. In this research, a shear stud was attached to the web of composite slag beam and welded to the bottom (tension 
zone) and top (compression zone) of the web at $25 \mathrm{~cm}$ interval for both sides of the web. As noticed in the laboratory, the shear stud shows that there is no slipping between concrete and steel in the composite section when the load is increased on the composite beam.

The present work researches the effect of replacing limestone aggregate with slag on the strength and other properties of composite beams (with shear studs). The cross section of composite slag beam ( $3000 \mathrm{~mm}$ steel length) with $80 \mathrm{~mm}$ top and bottom flanges is $160 \mathrm{~mm}$ high, thickness of flanges is $7.4 \mathrm{~mm}$, and web $5 \mathrm{~mm}$, and length of the beam is $3000 \mathrm{~mm}$ steel.

The shear studs were welded every $25 \mathrm{~cm}$ in the bottom tension zone and at the top compression zone on both sides of the web as shown in Figure 1.

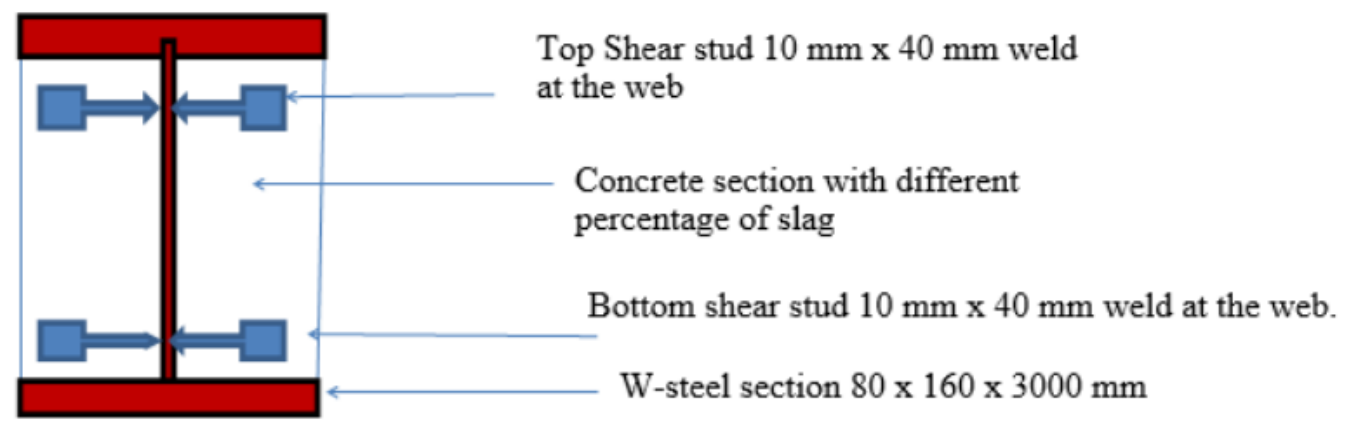

Figure 1 The cross section of the composite slag beam, (length of the beam $3000 \mathrm{~mm}$ )

During the testing of the composite beam, shear studs prevented slipping between the steel section and surrounded concrete and enhanced the load carrying capacity of the composite beam and reduced its deflection. Fifteen $150 \mathrm{~mm}$ cubes were tested: 3 cubes $0 \%$ slag (limestone to be as control mix), 3 cubes $25 \%$ slag, $50 \%$ slag, $75 \%$ slag, and $100 \%$ slag. The compressive strength shows significant increase as the percentage of slag increased to reach its maximum $100 \%$ slag. Table 1 and Figure 2 show 36.7\% stress increase and 13\% to 27\% deflection decrease between limestone ( $0 \%$ slag) and $100 \%$ slag concrete.

Many researchers conducted experimental studies on the use of slag aggregate in road pavements and in concrete aggregate. Manso ${ }^{1}$ at el (2006), conducted a comprehensive research on durability of concrete made with Electric arc furnace (EAF) slag as aggregate". EAF slag, a by-product of steel making recovered after the oxidizing process, is useful when employed as aggregate in hydraulic concrete and bituminous mixtures. Concrete made with EAF oxidizing slag as an aggregate shows good physical and mechanical properties and further study of its durability will ensure greater reliability in its usage. Tarawneh ${ }^{2}$ et al (2014), conducted a study on the effect of using steel slag aggregate on mechanical properties of concrete. This study presents an evaluation of the physical and mechanical properties and characteristics of steel slag aggregate concrete in comparison with the typical crushed limestone aggregate concrete. Hiraskar ${ }^{3}$ and Patil (2013), evaluated the use of blast furnace slag aggregate in concrete. Blast Furnace Slag from local industries has been utilized to find its suitability as a coarse aggregate in concrete making. Yildirim ${ }^{4}$ and Prezzi (October 2009), investigated the use of steel slag in subgrade applications and found that out of the 10-15 million metric ton of steel slag generated in the U.S.A every year, 50-70\% is used as aggregate for road and pavement construction.

\section{METHODOLOGY}

The author prepared 15 cubes, for investigation of the compressive strength of the composite section, $0 \%$ (limestone), $25 \%, 50 \%, 75 \%$, and $100 \%$ slag. In addition to that, ten composite 
Studying the Behaviour of Composite Slag Beam under Shear Stud Connector in Tension and Compression Zones

beams with cross section $80 \mathrm{~mm} \times 160 \mathrm{~mm} \times 3000 \mathrm{~mm}$ were tested. Two composite beam with $50 \%$ slag and $0 \%$ slag(limestone), in this case the stud attached at the bottom zone as shown in Table, Figure 3, Figure 3-a, and Figure 3-b. Two beams with the same dimension 50\% slag, top and bottom stud were attached to the web as in Table 4, Figure 4. Another two beams $25 \%$ slag with top and bottom stud as in Table 5. Moreover two beams $75 \%$ and $100 \%$ slag with top and bottom stud as in Table 6 . Finally, two beams 50\% slag and $0 \%$ slag(limestone) with top and bottom stud as shown in Table 6.

\subsection{Results}

Table 1 Comparison between average strength $(\mathrm{kN} / \mathrm{cm} 2)$ verses Different percentage of Slag Aggregate.

\begin{tabular}{|c|c|c|c|c|c|c|c|}
\hline $\begin{array}{c}\text { Type of } \\
\text { Aggregate }\end{array}$ & $\begin{array}{c}\text { \%of } \\
\text { Aggregate in } \\
\text { the Mix }\end{array}$ & $\begin{array}{c}\text { Cube } \\
1 \\
\text { Load } \\
\mathrm{kN}\end{array}$ & $\begin{array}{c}\text { Cube } \\
2\end{array}$ & $\begin{array}{c}\text { Cube } \\
3\end{array}$ & $\begin{array}{c}\text { Average } \\
\text { Strength } \\
\mathrm{kN} / \mathrm{cm} 2\end{array}$ & $\begin{array}{c}\text { Stress } \\
\mathrm{MPa}\end{array}$ & $\begin{array}{c}\text { Average } \\
\text { Load } \\
\mathrm{kN}\end{array}$ \\
\hline Slag & 100 & 1002 & 990 & 1025 & 4.47 & 44.69 & 1005.7 \\
\hline Slag & 75 & 890 & 910 & 905 & 4.01 & 40.1 & 901.7 \\
\hline Slag & 50 & 877 & 860 & 840 & 3.82 & 38.2 & 859 \\
\hline Slag & 25 & 790 & 788 & 799 & 3.52 & 35.2 & 792 \\
\hline Limestone & $100(0$ slag $)$ & 740 & 752 & 721 & 3.27 & 32.7 & 737.7 \\
\hline
\end{tabular}

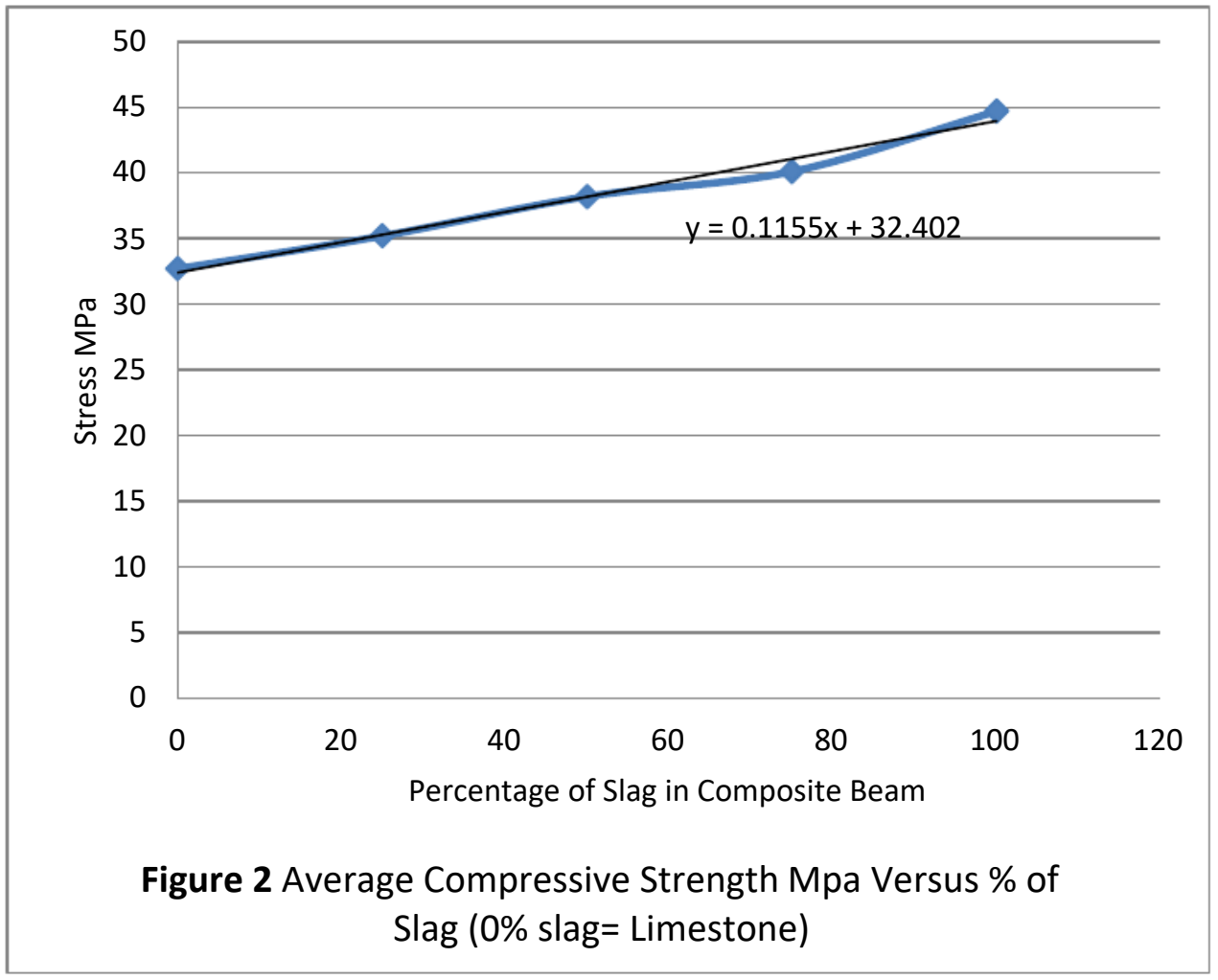

As shown in Table 1 and Figure 2, the strength of slag cubes compares with limestone increase by $7.5 \%, 17 \%, 22 \%$, and $36 \%$ as the percentage of slag increases from $25 \%, 50 \%$, $75 \%$, and $100 \%$, respectively. This indicates that the slag contributes highly to the mix design and durability of concrete element, since the slag aggregate is much stronger than limestone. 
Table 2 and Figure 3-a show less deflection in 50\% slag beam compared to that of the limestone beam. This indicates that beams made using slag aggregate are stiffer than made using limestone aggregate.

Table 2 Tension, compression strains and deflection for 50\% Slag versus limestone.

\begin{tabular}{|c|c|c|c|c|c|c|c|}
\hline & \multicolumn{2}{|c|}{ Bottom shear stud for 50\% Slag } & \multicolumn{3}{c|}{ Bottom shear stud for limestone } \\
\hline $\begin{array}{c}\text { Load } \\
\mathrm{kN}\end{array}$ & $\begin{array}{c}\text { Tension } \\
\text { Strain } \\
\text { (bottom } \\
\text { fiber) }\end{array}$ & $\begin{array}{c}\text { Compression } \\
\text { Strain (top } \\
\text { fiber) }\end{array}$ & $\begin{array}{c}\text { Deflection } \\
\mathrm{mm}\end{array}$ & Load kN & $\begin{array}{c}\text { Tension } \\
\text { Strain } \\
\text { (bottom } \\
\text { fiber) }\end{array}$ & $\begin{array}{c}\text { Compression } \\
\text { Strain (top } \\
\text { fiber) }\end{array}$ & $\begin{array}{c}\text { Deflection } \\
\mathrm{mm}\end{array}$ \\
\hline 0 & 0 & 0 & 0 & 0 & 0 & 0 & 0 \\
\hline 10 & 0.0002 & -0.00018 & 2.31 & 10 & 0.0002 & -0.00103 & 4.56 \\
\hline 25 & 0.0005 & -0.00043 & 6.86 & 25 & 0.00052 & -0.00132 & 9.32 \\
\hline 50 & 0.001 & -0.00093 & 12.44 & 50 & 0.00123 & -0.00189 & 15.86 \\
\hline 60 & 0.0013 & -0.00128 & 14.91 & 60 & 0.00166 & -0.00229 & 18.3 \\
\hline 67.5 & 0.0021 & -0.00204 & 22.76 & 66 & 0.00292 & -0.00282 & 25.25 \\
\hline 68.5 & 0.0025 & -0.00344 & 30.31 & 67 & 0.0032 & -0.00359 & 30.3 \\
\hline 71.5 & 0.003 & -0.004 & 43.38 & 68.5 & 0.00359 & -0.00457 & 36.2 \\
\hline
\end{tabular}

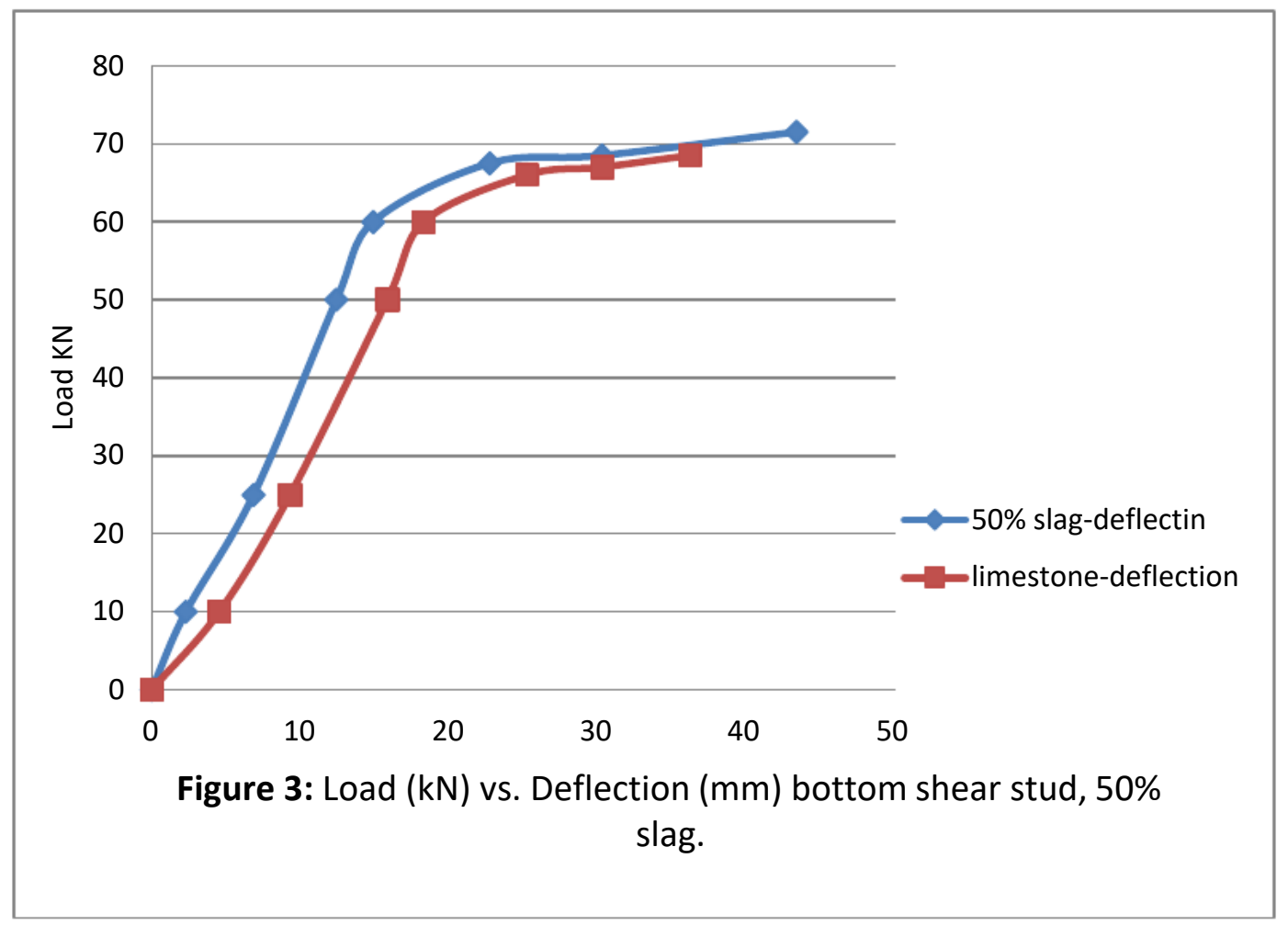


Studying the Behaviour of Composite Slag Beam under Shear Stud Connector in Tension and Compression Zones
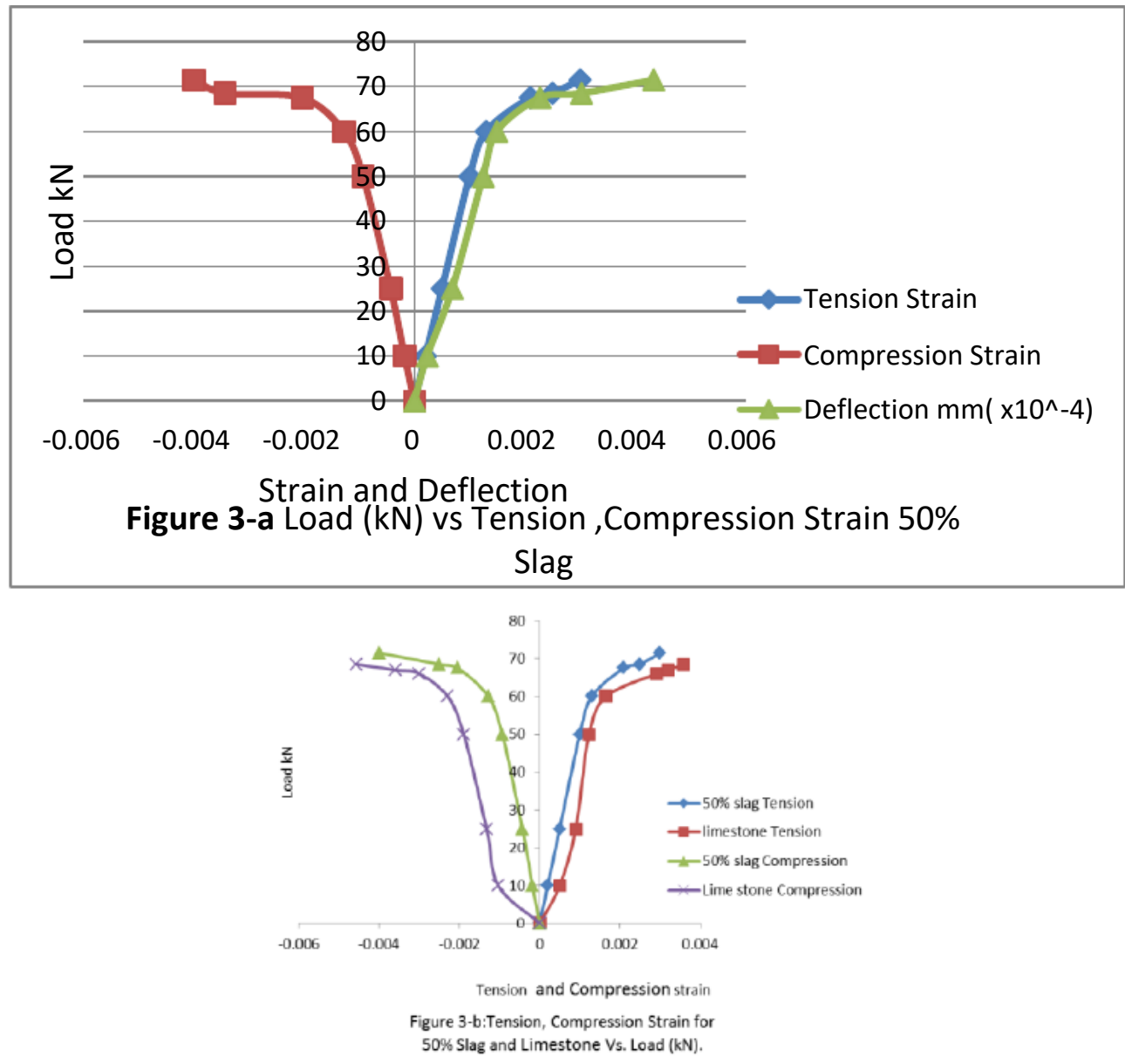

Figure 2-b shows that increasing the load resulted in increasing the strain for both limestone and $50 \%$ slag increase. But, the increment in compression strain for $50 \%$ slag is approximately twice that of limestone. However, the tension strain for $50 \%$ slag is about 1.5 times that of limestone. This result reflects stiffness increase and finally enhancement of modulus of elasticity.

From Table 3 and Figure 4, when the shear stud at the top and bottom and the slag is $50 \%$. The deflection was less when the stud at the bottom than that at the top of about $14 \%$. The tension stress decrease by average of $30 \%$ if load increase from $10 \mathrm{kN}-70 \mathrm{kN}$. For the compression strain, if the load increase from $10,25,50,60,67$, and $71 \mathrm{kN}$. This result indicates that putting the stud at the bottom (of two faces) of the web is more effective than that at the top location.

Table 3 Top and bottom shear stud 50\% slag.

\begin{tabular}{|l|l|l|l|l|l|l|l|}
\hline \multicolumn{3}{|c|}{ Top Stud Connector 50\% Slag } & \multicolumn{4}{c|}{ Bottom shear stud for 50\% Slag } \\
\hline Load & Tension & Compression & Deflection & $\begin{array}{l}\text { Load } \\
\mathrm{kN}\end{array}$ & $\begin{array}{l}\text { Tension } \\
\text { Strain } \\
\text { (bottom } \\
\text { fiber) }\end{array}$ & Compression & Deflection \\
\hline $\mathrm{kN}$ & & & & & & & $\mathrm{mm}$ \\
\hline 0 & 0 & 0 & 0 & 0 & 0 & 0 & 0 \\
\hline 10 & 2.96 & -1.92 & 2.4 & 10 & 2 & -1.8 & 2.31 \\
\hline 25 & 5.76 & -6 & 6 & 25 & 5 & -4.3 & 4.86 \\
\hline 50 & 10.56 & -9.84 & 12.25 & 50 & 10 & -8.3 & 9.44 \\
\hline
\end{tabular}




\begin{tabular}{|l|l|l|l|l|l|l|l|}
\hline \multicolumn{3}{|c|}{ Top Stud Connector 50\% Slag } & \multicolumn{5}{c|}{ Bottom shear stud for 50\% Slag } \\
\hline 60 & 21.68 & -17.36 & 16.45 & 60 & 13 & -12.8 & 13.91 \\
\hline 65 & 27.5 & -33.84 & 21.75 & 67.5 & 21 & -20.4 & 22.76 \\
\hline 67.5 & 52.2 & -43.2 & 26.15 & 68.5 & 25 & -34.4 & 30.31 \\
\hline 68.5 & 61.3 & -52.4 & 33.5 & 71.5 & 30 & -40 & 43.38 \\
\hline 69.5 & 66.9 & -60 & 35.9 & & & & \\
\hline 71.8 & 72.6 & -68 & 39.6 & & & & \\
\hline
\end{tabular}

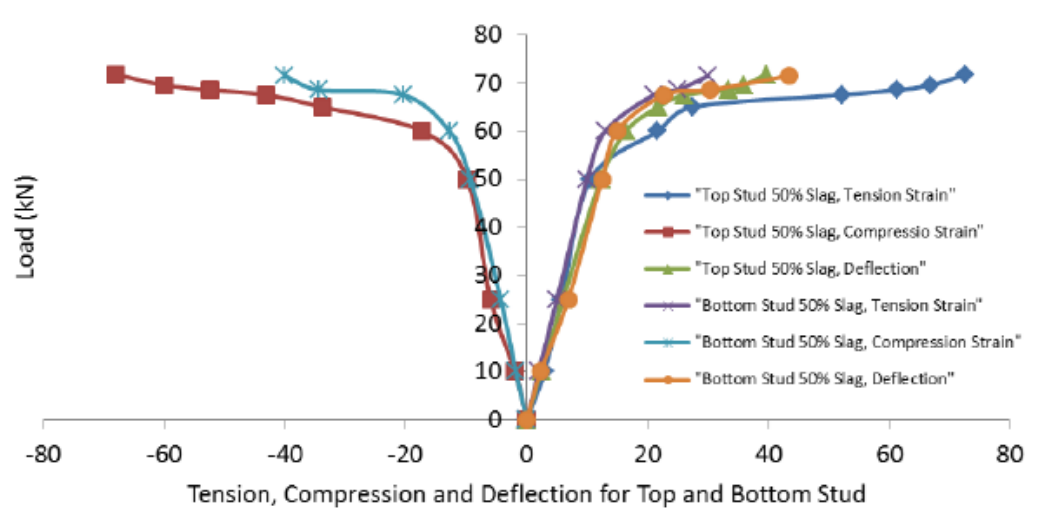

Figure 4: Top and Bottom Stud with Tension and Compression strain

When percentage of slag is $25 \%$, and $50 \%$ as shown in Table 4 with shear stud at the top deflection, tension and compression strains were less for $50 \%$ slag than that of $25 \%$.

Table 4 25\% and 50\% Slag versus tension and compression (strains) and deflection.

\begin{tabular}{|c|c|c|c|c|c|c|c|}
\hline \multicolumn{3}{|c|}{ Top Stud Connector 25\% Slag } & \multicolumn{4}{c|}{ Top Stud Connector 50\% Slag } \\
\hline $\begin{array}{c}\text { Load } \\
\mathrm{kN}\end{array}$ & $\begin{array}{c}\text { Tension } \\
\text { Strain }\end{array}$ & $\begin{array}{c}\text { Compression } \\
\text { Strain }\end{array}$ & $\begin{array}{c}\text { Deflection } \\
\mathrm{x} 0.01 \mathrm{~mm}\end{array}$ & $\begin{array}{c}\text { Load } \\
\mathrm{kN}\end{array}$ & Tension & Compression & Deflection \\
\hline 0 & 0 & 0 & 0 & 0 & 0 & 0 & 0 \\
\hline 10 & 0.0003 & -0.00024 & 2.23 & 10 & 0.000296 & -0.000192 & 2.4 \\
\hline 25 & 0.0006 & -0.00066 & 6.23 & 25 & 0.000576 & -0.0006 & 6.0 \\
\hline 50 & 0.00142 & -0.00108 & 12.98 & 50 & 0.001056 & -0.000984 & 12.25 \\
\hline 60 & 0.00235 & -0.00185 & 17.23 & 60 & 0.002168 & -0.001736 & 16.45 \\
\hline 66 & 0.00302 & -0.00344 & 24.83 & 65 & 0.00275 & -0.003384 & 21.75 \\
\hline 67.5 & 0.0056 & -0.00443 & 29.83 & 67.5 & 0.00522 & -0.00432 & 26.15 \\
\hline 69 & 0.007 & -0.0051 & 46.31 & 68.5 & 0.00613 & -0.00524 & 33.5 \\
\hline & & & & 69.5 & 0.00669 & -0.0060 & 35.9 \\
\hline & & & & 71.8 & 0.00726 & -0.0068 & 39.6 \\
\hline
\end{tabular}

Table 5 shows that when the slag is at $75 \%$, and $100 \%$ and the shear stud is at the top, the deflection decreases at $100 \%$ slag more than that at $75 \%$ slag, even though, the tension strain increases as the load increases. However, the strain in compression decreasing, while the load increasing. Table 5 shows that tensile strain increases as the load increases while the compression strain decreases as the load increase. It was noticed that the tension strain for $75 \%$ slag is less than that for $100 \%$ slag, but the compression strain for $75 \%$ slag is greater than that for $100 \%$ slag and decreased when increasing the load for $75 \%$, but it decreased at $100 \%$ slag when increasing the load. 
Studying the Behaviour of Composite Slag Beam under Shear Stud Connector in Tension and Compression Zones

Table 5 75\%, 100\% Slag versus tension, compression strains and deflection.

\begin{tabular}{|l|l|l|l|l|l|l|l|}
\hline \multicolumn{3}{|c|}{ Top Stud Connector 75\% Slag } & \multicolumn{4}{c|}{ Top Stud Connector 100\% Slag } \\
\hline \multirow{2}{*}{ Load kN } & Tension & Compression & Deflection & Load & Tension & Compression & Deflection \\
& Strain & Strain & X 0.01mm & kN & Strain & Strain & X 0.01mm \\
0 & 625 & 1140 & 1642 & 0 & 819 & 845 & 1546 \\
\hline 10 & 657 & 1121 & 1752 & 10 & 840 & 778 & 1640 \\
25 & 689 & 1080 & 2100 & 25 & 878 & 746 & 1965 \\
50 & 741 & 1035 & 2747 & 50 & 952 & 680 & 2570 \\
\hline 60 & 880 & 940 & 3140 & 62 & 1020 & 636 & 3057 \\
65 & 951 & 769 & 3780 & 68 & 1115 & 554 & 3580 \\
\hline 67.5 & 1250 & 653 & 4510 & 70 & 1210 & 460 & 4033 \\
\hline 68.5 & 1370 & 545 & 5267 & 72 & 1300 & 365 & \\
70.5 & 1430 & 431 & 6017 & 75.5 & 1470 & 241 & \\
\hline 72.5 & 1509 & 391 & 6745 & & & & \\
\hline
\end{tabular}

As shown in Table 6, when the stud is at the top and bottom of the web 50\% slag compares with limestone. The deflection decreases from 6\%-20\% compared to $50 \%$ slag with limestone at the same location of the stud at the top and bottom, while the compression and tension strains remain mostly close to each other.

Table 6 Bottom and top stud for $0 \%-50 \%$ slags.

\begin{tabular}{|c|c|c|c|c|c|c|c|}
\hline \multicolumn{4}{|c|}{ Bottom and Top Studs 50\% Slag } & \multicolumn{4}{|c|}{ Bottom and Top Studs Limestone } \\
\hline $\begin{array}{l}\text { Load } \\
\mathrm{kN}\end{array}$ & $\begin{array}{l}\text { Tension } \\
\text { Strain gage } \\
\text { (bottom } \\
\text { fiber) } \\
\times 0.8 \times 10^{-5} \\
\end{array}$ & $\begin{array}{l}\text { Compression } \\
\text { Strain (top } \\
\text { fiber) } \times 0.8 \times 10^{-} \\
5\end{array}$ & $\begin{array}{c}\text { Deflection } \\
\mathrm{x} 0.01 \mathrm{~mm}\end{array}$ & $\begin{array}{l}\text { Load } \\
\mathrm{kN}\end{array}$ & $\begin{array}{c}\text { Tension } \\
\text { Strain } \\
\text { (bottom } \\
\text { fiber) } \\
\times 0.8 \times 10^{5} \\
\end{array}$ & $\begin{array}{l}\text { Compression } \\
\text { Strain (top } \\
\text { fiber) } \times 0.8 \times 10^{-} \\
5\end{array}$ & $\begin{array}{c}\text { Deflection } \\
\mathrm{x} 0.01 \mathrm{~mm}\end{array}$ \\
\hline 0 & 790 & 824 & 1294 & 0 & 807 & 830 & 1389 \\
\hline 10 & 898 & 807 & 1525 & 10 & 844 & 810 & 1622 \\
\hline 25 & 843 & 687 & 1871 & 25 & 875 & 778 & 2010 \\
\hline 50 & 954 & 657 & 2419 & 50 & 949 & 726 & 2715 \\
\hline 60 & 1182 & 647 & 2845 & 60 & 1003 & 706 & 3395 \\
\hline 65 & 1218 & 621 & 4018 & 67 & 1270 & 640 & 3880 \\
\hline 69 & 1248 & 591 & 4329 & 69 & 1420 & 588 & 4510 \\
\hline 73 & 1285 & 552 & 5217 & 70 & 1612 & 522 & 4880 \\
\hline
\end{tabular}

\section{DISCUSSION OF THE RESULTS}

The shear studs which were attached to the web of the composite slag beam show that there was no slipping occurred throughout the gradually loading between slag concrete and steel section. This new idea enhanced the load carrying capacity of the composite slag beam. The compressive strength increased by $36 \%$, when the percentage of slag changed from $0 \%$ (limestone) to $100 \%$. This significant result strongly indicates the need of using slag in the concrete mix. The average deflection decreased by $18 \%$ as the percentage of slag increased from $0 \%$ to $50 \%$ of the mix. For the same ratio of slag, the strain decreased by $23 \%$ in the tension zone and $60 \%$ in the compressive zone. The strain results show that the higher the percentage of slag in the composite beam the higher the stiffness of composite beam in tension and compression zones. However, the average deflection decreases by $12 \%$ at $50 \%$ slag content compared with $0 \%$ slag (limestone) when the shear stud is attached only to tension zone (the bottom part of the composite beam section). It will reduce the strain in tension and compression zones. 


\section{CONCLUSION}

Regarding deflection and strain, the study shows a significance of using stud in tension zone rather than compression zone. The use of slag up to $50 \%$, increase the strength of concrete, increase modulus of elasticity, and increases the stiffness of the composite slag beam and decreases the deflection and strain.

The author highly recommends further studies on composite column slag and location of stud.

\section{REFERENCES}

[1] Juan M. Manso et al,"Durability of concrete made with EAF slag as aggregate". Cement and concrete omposites, Volume 28, Issue 6, July 2006, Pages 528-534.

[2] V. Subathra Devi, B.K. Gnanavel. "Properties of concrete manufactured using steel slag". Procedia Engineering, Volume 97, 2014, Pages 95-104.

[3] Son Hoang Trinh, Dong Van Dao, Quynh Anh Thi Bui. A Study on Effect of Aggregate Grading on Compressive Strength and Workability of Fly Ash Based Geopolymer Concrete Totally Using Steel Slag Aggregate. International Journal of Civil Engineering and Technology, 8(5), 2017, pp. 1460-1467.

[4] $12^{\text {th }}$ Global congress on manufacturing and management GCMM 2014. Elsevier.

[5] S.Ranga, G. Kaur, S.Salhotra, R.Saharma, "Effect of slag in various fresh and mechanical properties of mortar, "International journal of civil engineering.Vol.1,Sp1.Issue 1(2014)

[6] J. John Christy Vijay, A. Lawrence and G. Arthanareeswaran, Analytical Tool for Analysing Slagging Characteristic of High Ash Coals in Utility Boilers. International Journal of Mechanical Engineering and Technology, 8(3), 2017, pp. 185-196.

[7] Sultan A. Tarawneh, Emhaidy S. Gharaibeh and Falah M. Saraireh.” Effedt of using steel slag aggregate on mechanical properties of concrete". American Journal of Applied Sciences 11 (5): 700-706, 2014.

[8] Karthickraja R and Vignesh J, An Experimental Investigation on Concrete by Partial Replacement of Copper Slag with Fine Aggregate and Ceramic Waste with Coarse Aggregate. International Journal of Civil Engineering and Technology, 9(3), 2018, pp. 9097.

[9] Ramzi Taha et al, "Use of local discarded materials in concrete". International Journal of Sustainable Built Environment, Volume 3, Issue 1, June 2014, Pages 35-46.

[10] K.G. Hiraskar and Chetan Patil," Use of Blast Furnace Slag Aggregate in Concrete International Journal of Scientific \& Engineering Research, Volume 4, Issue 5, May 2013.

[11] J. Manoj Kumar and N. Gopikrishna, Comparative Studies on Mechanical Characteristics of Granulated Blast Furnace Slag and Fly Ash Reinforced Aluminium Composites, International Journal of Mechanical Engineering and Technology 8(11), 2017, pp. 277284.

[12] Iren Zeynep Yildirim and Monica Prezzi, "Use of Steel Slag in Subgrade Applications", Joint Transportation Research Program 550 Stadium Mall Drive Purdue University October 2009, West Lafayette, IN 47907-2051 